\title{
Analisis Broker Contract Kepengurusan Surat Izin Mengemudi dalam Islamic Framing (Studi Kasus Satpas Polres Demak)
}

\author{
Hadi Purnomo'), Bayu Tri Cahya ${ }^{2 *}$, Muhammad Lutfi Kuncoro ${ }^{3)}$, Suparwi ${ }^{4)}$ \\ ${ }^{1}$ Perguruan Tinggi Ilmu Kepolisian (PTIK) \\ ${ }^{2,3,4}$ FEBI IAIN Kudus \\ *Email korespondensi: cahyab380@gmail.com
}

\begin{abstract}
Indonesia's bureaucratic administration is quite famous for its complexity. Starting from the procedures it is long and many of them, so the service that is less efficient in serving many people. Nowadays, until technology enters the modern era in driver's licence management, services are still not optimal, because technology is only limited to being glanced at without being touched and considered to be improved to control service efficiency. Brokers are here to sneak in, offering convenience, speed to prospective driver's licence applicants, so that transactions can be made between them. However, this incident made it unclear for the community. On the other hand, the actions of brokers are very helpful for driver's licence applicants in their management. With the phenomenological qualitative methodology, it will be illustrated that the contract exists between the two parties (brokers and service users), because the clarity of a contract is the most important thing to tie cooperation between fellow social beings so that no one is harmed and is not partial. This research was conducted at the Demak Resort Police with a phenomenological approach and using interview data collection techniques, observation and documentation. The results of this study reveal that the contract that exists between the driver's licence broker and service users in the management of the driver's licence is the Ijarah Agreement. And this contract transaction is a legal thing. In general, the process of the driver's licence management mechanism by brokers is haram. Because there is an element of risywah or bribery in the mechanism.
\end{abstract}

Keywords: Brokers, Ijarah Agreement, Driver's Licence Management

Saran sitasi: Purnomo, H., Cahya, B. T., Kuncoro, M. L., \& Suparwi. (2021). Analisis Broker Contract Kepengurusan Surat Izin Mengemudi dalam Islamic Framing (Studi Kasus Satpas Polres Demak). Jurnal Ilmiah Ekonomi Islam, 7(01), 412-424. doi: http://dx.doi.org/10.29040/jiei.v7i1.1861

DOI: http://dx.doi.org/10.29040/jiei.v7i1.1861

\section{PENDAHULUAN}

Dewasa ini dalam kehidupan bermasyarakat, banyak dari mereka (masyarakat) yang sibuk akan kegiatannya masing-masing. Masyarakat sebagai salah satu makhluk sosial dalam hal ini manusia tidak bisa memenuhi kebutuhan hidupnya sendiri, maka dari itu mereka memerlukan bantuan dari orang lain. Oleh karena sifat saling ketergantungan yang dimiliki oleh manusia tersebut, maka diantara mereka terdapat suatu sikap saling bantu-membantu, gotong royong dan lain sebagainya sebagai rasa solidaritas makhluk sosial. Hubungan antara individu manusia dengan individu manusia lainnya ini biasanya terjadi dikarenakan di antara mereka terdapat kepentingankepentingan yang saling membutuhkan. Hubunganhubungan itu misalnya kerja sama di berbagai bidang yaitu, pinjam meminjam, penggunaan jasa, sewamenyewa serta kegiatan lainnya yang bersifat sosial.

Salah satu kegiatan manusia sebagai makhluk sosial yang membutuhkan bantuan orang lain karena kesibukannya di bidang jasa adalah Perantara atau Makelar atau Calo atau Broker. Dalam KBBI Daring (dalam jaringan/online), kata calo berarti orang yang menjadi perantara dan memberikan jasanya untuk menguruskan sesuatu berdasarkan upah (KBBI Daring, 2019). Profesi ini adalah profesi legal, sah dan terhormat yang biasanya ada di dunia transaksi barang dan jasa baik lokal, domestik, regional maupun internasional (www. Kompasiana.com).

Jasa atau layanan yang diberikan oleh profesi ini adalah menemukan pihak yang berkebutuhan tertentu untuk dibantu pengurusannya. Dari jasa atau layanan 


\section{Jurnal Ilmiah Ekonomi Islam, 7(01), 2021, 413}

inilah profesi ini mendapatkan pendapatan. Broker (Calo) bekerja sebagai pemberi jasa alternatif atau jalan pintas bagi seseorang secara tidak resmi. Tidak ada patokan khusus berapa persentase dari harga jual (beli) jasa broker yang diberikan sebagai pendapatan. Semuanya tergantung dari produk yang diperdagangkan dan yang paling penting adalah kesepakatan dari pihak yang bertransaksi. Etikanya seorang broker mendapatkan fee sebagai pendapatannya dari layanan yang diberikan dari salah satu pihak yang bertransaksi. Sampai di sini jika kata broker digunakan dalam konteks dunia jasa yang profesional, kata broker bermakna positif.

Dalam prosesnya seorang broker akan berusaha mencari keuntungan dengan menggandakan harga asli suatu produk atau jasa, memberikan penawaran dengan harga yang besar dan tentunya berbeda dari harga sebenarnya. Pekerjaan ini juga menjadi pekerjaan yang dipandang rendah bagi sebagian kalangan karena penghasilannya yang tidak jelas dan praktiknya yang cenderung mengelabuhi atau menipu targetnya (www.suduthukum.com) . Dari yang ingin untung sendiri dengan mengorbankan kepentingan salah satu pihak dan tidak bertanggung jawab atas risiko yang mungkin terjadi, sampai yang profesional dengan benar-benar menjembatani kepentingan pihakpihak yang dihubungkan dan dapat dipertanggungjawabkan. Hingga tak sedikit orang yang memiliki stigma bahwa makelar adalah suatu kegiatan yang negatif untuk dilakukan.

Tak terelakkan dari Jasa Broker, Kepengurusan Surat Izin Mengemudi (SIM) pun menjadi salah satu sasaran kesempatan untuk menjalankan bisnis ini oleh Broker. Islam adalah suatu ajaran dan jalan hidup yang utuh dan terpadu (comprehensive way of life). Yang memberikan panduan yang dinamis dan lugas terhadap semua aspek kehidupan termasuk sektor bisnis dan transaksi (Muhammad Syafi'i Antonio, 2001). Broker merupakan orang yang bertransaksi yang tergolong dalam jual beli namun yang diperjualbelikan adalah jasa. Islam menentukan bahwa jual beli bukan merupakan aktivitas ekonomi untuk mencari laba semata, kita harus memperhatikan nilai-nilai atau etika keislaman dalam setiap hal yang kita lakukan termasuk bertransaksi jual beli (Rara Berthania, 2017).

Jual beli dalam prakteknya harus dikerjakan secara jujur agar tidak terjadi saling merugikan, menghindari kemudaratan dan tipu daya, sebaliknya justru dapat mendatangkan kemaslahatan. Dalam ajaran Islam, seorang muslim di dalam melakukan jual beli harus memperhatikan dan mempertimbangkan apakah jual beli tersebut sudah sesuai dengan prinsip syariah (Rara Berthania, 2017). Jual beli dalam Islam memiliki prinsip-prinsip yaitu tidak boleh merugikan salah satu pihak (baik penjual atau pembeli), dan dilakukan atas dasar suka sama suka, bukan karena adanya paksaan, dalam Al-Qur'an Surat An-Nisa' ayat 29

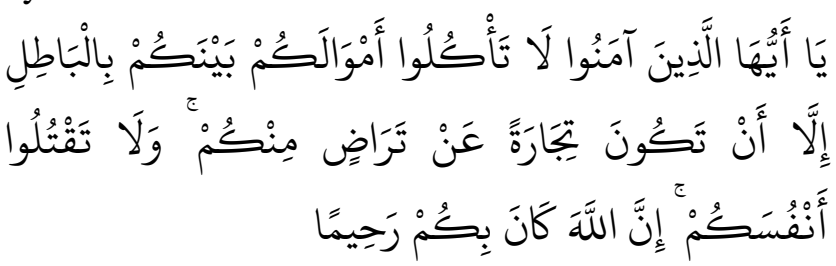

Artinya: "Hai orang-orang yang beriman, janganlah kamu saling memakan harta sesamamu dengan jalan yang batil, kecuali dengan jalan perniagaan yang berlaku dengan suka sama-suka di antara kamu. Dan janganlah kamu membunuh dirimu; sesungguhnya Allah adalah Maha Penyayang kepadamu.".

Perkembangan ekonomi syariah di Indonesia yang meningkat membuat masyarakat semakin tertarik menerapkan prinsip-prinsip jual beli Islam atau Syariah dalam setiap transaksi yang mereka lakukan. Jual beli Syariah yang mengharamkan adanya riba membuat masyarakat merasa lebih adil dan diuntungkan (Rara Berthania, 2017). Oleh karena itu perkembangan Broker yang dalam hal ini menerapkan prinsip-prinsip Syariah juga semakin meningkat.

Islam memperbolehkan jual beli dengan wakil, karena dalam memenuhi kebutuhan hidupnya manusia belum tentu dapat melakukannya secara pribadi. Manusia membutuhkan wakilnya yang dapat dipercaya agar dapat membantu memenuhi kebutuhan hidup (Rara Berthania, 2017). Wakil tersebut adalah orang yang bekerja sebagai perantara, yakni perantara antara penjual dan pembeli untuk melakukan transaksi jual beli, dalam hadis yang diriwayatkan Ibnu Umar, bahwa Nabi SAW, bersabda "Sesungguhnya Rasulullah SAW, pernah memberikan pekerjaan kepada penduduk khabar dengan upah separuh dari apa yang dikerjakan seperti buah, bahan atau tanaman (Ahmad Mudjab Mahalli, 2004).” Hadist tersebut menerangkan bahwa pekerjaan sebagai seorang perantara atau makelar memanglah ada dan bukanlah pekerjaan yang haram asalkan sesuai dengan syariat Islam. 


\section{Jurnal Ilmiah Ekonomi Islam, 7(01), 2021, 414}

Pada rasionalitas instrumental pengguna jasa calo SIM beralasan bawasanya ia menggunakan jasa calo karena penggunaan calo akan mempermudah dan mempercepat proses pengurusan SIM mereka, selain itu terdapat informan yang sudah mengalami kegagalan berkali-kali pada ujian paktek merasa terbantu dengan adanya calo SIM yang membantunya. Sedangkan pada tipe tindakan afektif, calon pemohon SIM menggunakan calo karena adanya dorongan dalam bentuk hubungan emosional antara calon pemohon SIM dengan calo SIM. Dan tipe tindakan yang terkahir yakni tradisional, pengguna jasa calo SIM menggunakan calo karena sudah adanya kebiasaan yang turun-temurun dari keluarga atau orang terdekatnya untuk menggunakan calo pada setiap pengurusan SIM mereka.

Penelitian ini mempunyai target tujuan yang sangat penting yaitu: 1) Menganalisis akad-akad yang terjadi oleh para broker dalam praktik kepengurusan Surat Izin Mengemudi; 2) Mengetahui bagaimana pandangan Islam terhadap praktik broker dalam kepengurusan Surat Izin Mengemudi. Oleh karena itu, dengan berbagai gambaran di atas, maka penelitian Analisis Broker Contract Kepengurusan Surat Izin Mengemudi dalam Islamic Framing di SATPAS POLRES DEMAK menjadi menarik untuk dilakukan.

\section{KAJIAN PUSTAKA}

\subsection{Contract (Akad)}

Dalam Kamus Lengkap Ekonomi dinyatakan bahwa: Contract (kontrak) adalah suatu perjanjian legal yang dapat dilaksanakan antara dua pihak atau lebih. Suatu kontrak meliputi kewajiban bagi kontraktor yang dapat dinyatakan secara lisan maupun tertulis. Sebagai contoh, suatu perusahaan mempunyai perjanjian untuk memasok suatu produk ke perusahaan lain pada waktu tertentu dan ukuran tertentu. Kedua belah pihak akan terikat untuk menepati perjanjian mereka dalam penjualan dan pembelian dari barang (C.Pass, Bryan Lowes dan Leslie Davies, 1999).

Sedangkan definisi akad menurut istilah fuqaha, dapat dirumuskan sebagai berikut:

$$
\text { ارتباط الايجاب بقبول على وجه مشروع يثبت التراض }
$$

"Perikatan antara ijab dan qabul dengan cara yang dibenarkan syara', yang menetapkan keridahan kedua belah pihak."

Definisi lain akad menurut istilah adalah pertalian ijab dan qabul sesuai dengan kehendak syariat yang berpengaruh pada objek perikatan. Yang dimaksud "sesuai dengan kehendak syariat" adalah bahwa seluruh perikatan yang dilakukan oleh dua belah pihak atau lebih, apabila tidak sejalan dengan kehendak syara', misalnya kesepakatan untuk melakukan transaksi riba, menipu orang lain, atau merampok kekayaan orang lain. Sementara yang dilakukan "berpengaruh pada objek perikatan" adalah terjadinya perpindahan pemilikan suatu pihak (yang melakukan ijab) kepada pihak yang lain (yang menyatakan qabul) (Abdul Azis Dahlan, 1996).

\section{Rukun Akad}

Para ulama berbeda pendapat dalam menentukan rukun dan syarat akad. Ulama Hanafiyah berpendapat bahwa rukun akad itu hanya satu, yaitu shighat al'aqd (ijab dan qabul), adapun pihakpihak yang lakukan akad dan objek akad merupakan syarat-syarat akad, karena mereka berpendapat bahwa yang dikatakan rukun itu adalah suatu yang esensi yang berada dalam akad itu sendiri. Sedangkan jumhur ulama berpendapat bahwa rukun akad itu ada tiga, yaitu (Sri Sudiarti, 2018):

i. Aqid (Orang yang melakukan akad)

Aqid adalah pihak-pihak yg melakukan transaksi, atau orang yang memiliki hak dan yang akan diberi hak, seperti dalam hal jual beli mereka adalah penjual dan pembeli

ii. Ma'qud 'Alaih (objek transaksi)

Ma'qud 'alaih atau objek transaksi, harus memenuhi beberapa persyaratan sebagai berikut:

(1) Objek transaksi harus ada ketika akad atau kontrak sedang dilakukan.

(2) Objek transaksi harus berupa mal mutaqawwim (harta yang diperbolehkan syara' untuk ditransaksikan) dan dimiliki penuh oleh pemiliknya.

(3) Objek transaksi bisa diserahterimakan saat terjadinya akad, atau dimungkinkan dikemudian hari.

(4) Adanya kejelasan tentang objek transaksi.

(5) Objek transaksi harus suci, tidak terkena najis dan bukan barang najis.

\section{iii. Shighat}

Shigat, yaitu Ijab qabul merupakan ungkapan yang menunjukkan kerelaan atau kesepakatan dua pihak yang melakukan kontrak atau akad. Definisi ijab menurut ulama Hanafiyah adalah penetapan perbuatan tertentu yang menunjukkan keridhaan yang diucapkan oleh orang pertama, baik yang 
menyerahkan maupun menerima, sedang qabul adalah orang yang berkata setelah orang yang mengucapkan $i j a b$, yang menunjukkan keridhaan atas ucapan orang yang pertama (Sri Sudiarti, 2018).

\subsection{Broker (Calo)}

Calo merupakan orang yang menjadi perantara dan memberikan jasanya untuk menguruskan sesuatu berdasarkan upah (KBBI.kemdikbud.go.id). Bahasa halus untuk menyebut calo adalah biro jasa. Profesi ini terlahir sebagai akibat dari asumsi di tengah masyarakat bahwa mengurus surat-surat itu sulit. Orang yang malas membuang waktu untuk mengurus keperluan terkait keruwetan birokrasi akan lebih suka membayar orang lain untuk menguruskannya. Biro jasa bisa menjadi menjebatan anatara seseorang yang tidak memiliki waktu untuk mengurus kelengkapan atau perpanjangan berkaitan dengan kuwajiban yang harus di jalankannya.

\section{Dasar Hukum Percaloan}

Calo dibolehkan dalam Islam dengan syaratsyarat tertentu. Adapun dalil-dalilnya adalah sebagai berikut :

Pertama : Firman Allah :

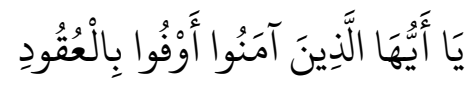

"Wahai orang-orang beriman sempurnakanlah akad-akad (janji-janji) kalian “ (Qs. AlMaidah:1)

Pada ayat di atas, Allah memerintahkan orangorang beriman untuk menyempurnakan akad-akad, termasuk di dalamnya menyempurnakan perjanjian seorang pengguna jasa calo dengan calo.

Kedua : Hadist riwayat Qais bin Abi Gorzah, bahwasanya ia berkata :

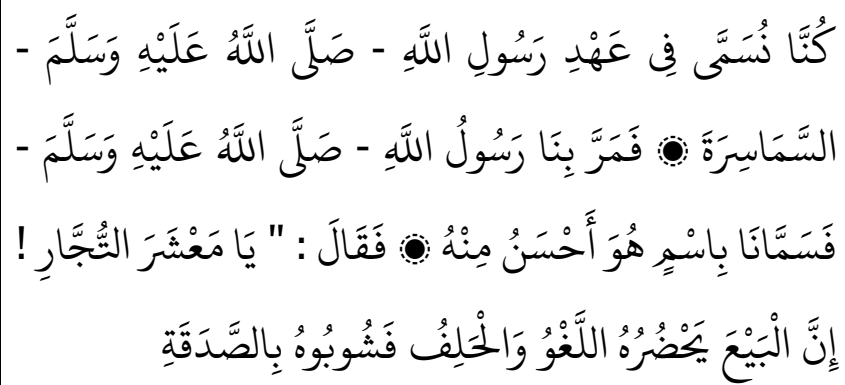

"Kami pada masa Rasulullah shallallahu 'alaihi wassalam disebut dengan "samasirah" (calo/makelar), pada suatu ketika Rasulullah shallallahu 'alaihi wassalam menghampiri kami, dan menyebut kami dengan nama yang lebih baik dari calo, beliau bersabda : "Wahai para pedagang, sesungguhnya jual beli ini kadang diselingi dengan kata-kata yang tidak bermanfaat dan sumpah (palsu), maka perbaikilah dengan (memberikan) sedekah" (Shahih, HR Ahmad, Abu Daud, Tirmidzi, Nasai dan Ibnu Majah)

Hadist di atas menunjukkan bahwa pekerjaan calo sudah ada sejak masa Rasulullah SAW, dan beliau tidak melarangnya, bahkan menyebut mereka sebagai pedagang (www.ahmadzain.com).

Ketiga : Calo adalah pekerjaan yang dibutuhkan masyarakat, karena ada sebagian masyarakat yang sibuk, sehingga tidak bisa mencari sendiri barang yang dibutuhkan, maka dia memerlukan calo untuk mencarikannya. Sebaliknya, sebagian masyarakat yang lain, ada yang mempunyai barang dagangan, tetapi dia tidak tahu cara menjualnya, maka dia membutuhkan calo untuk memasarkan dan menjualkan barangnya (www.ahmadzain.com).

Adapun peneliti mendifinisikan Broker Contract adalah Akad yang terjadi dalam proses mekanisme kepengurusan SIM yang dilakukan oleh calo SIM dan pengguna jasa calo SIM.

\subsection{Surat Izin Mengemudi}

Surat Izin Mengemudi (SIM) adalah bukti registrasi dan identifikasi yang diberikan oleh Polri kepada seseoraang yang telah memenuhi persyaratan administrasi, sehat jasmani dan rohani, memahami peraturan lalu lintas dan trampil mengemudikan kendaraan bermotor (Polri, 2012).

Setiap pengemudi kendaraan bermotor wajib memiliki SIM peraturan ini tercantum pada Pasal 18 (1) UU No. 14 Th 1992 tentang Lalu-lintas dan Angkutan Jalan, bahwa setiap pengemudi kendaraan bermotor diwilayah wajib memiliki Surat Izin Mengemudi (SIM) (https://polri.go.id/layanansim.php)

\section{Kerangka Pemikiran}

Kerangka berfikir digunakan sebagai acuan agar peneliti memiliki arah penelitian yang sesuai dengan tujuan penelitian. Adapun kerangka berpikir dari penelitian ini adalah sebagai berikut : 
Gambar 1

Kerangka Berfikir

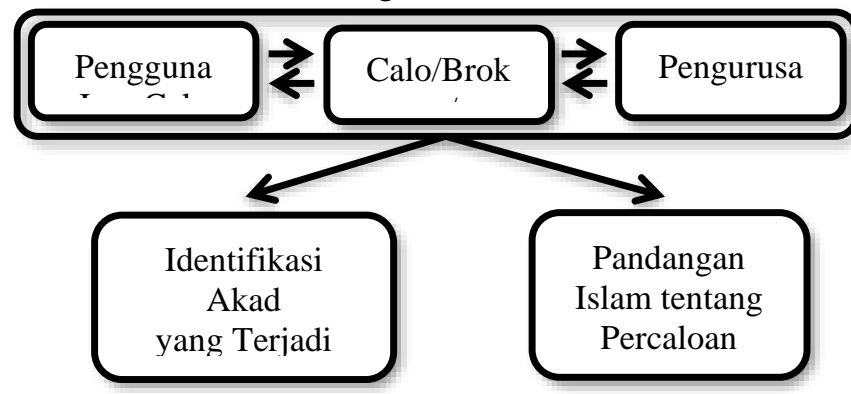

\section{METODE PENELITIAN}

Jenis penelitian ini menggunakan penelitian kualitatif. Metode kualitatif cenderung dikaitkan dengan memahami dunia sosial dan bagaimana mengekspresikan pemahaman melalui bahasa, suara, gambar, gaya pribadi, dan ritual social (Christine Daymon and Immy Holloway, 2002). Metode kualitatif berusaha mencari arti dan menafsirkan makna suatu peristiwa interaksi tingkah laku manusia berdasarkan pengalaman partisipan dalam situasi tertentu menurut perspektif peneliti sendiri untuk memahami obyek yang diteliti secara mendalam (J.R, Raco, 2010).

Dalam penelitian ini peneliti menggunakan pendekatan fenomenologi, pada konteks penelitian kualitatif, fenomena merupakan sesuatu yang muncul dalam kesadaran peneliti dengan menggunakan cara tertentu menjadi tampak dan nyata (Muri Yusuf, 2017). Fenomenologi secara umum dikenal sebagai pendekatan yang dipergunakan untuk membantu memahami berbagai gejala atau fenomena sosial dalam masyarakat (Stefanus Nindito, 2005). Penelitian kualitatif dengan pendekatan fenomenologi bertujuan untuk menghadirkan kesadaran dan pemahaman mendalam tentang bagaimana manusia mengalami sesuatu (J. Saldana, 2015). Pendekatan fenomenologi mencoba mengungkap makna konsep atau fenomena pengalaman yang didasari oleh kesadaran yang terjadi pada beberapa individu (Juliansyah Noor, 2012). Disini peniliti berlaku sebagai fasilitator yang ikut memberi makna pada realitas yang dikonstruksi oleh subjek penelitian.

\section{HASIL DAN PEMBAHASAN}

Calo merupakan fenomena sosial yang tak asing bagi mayoritas masyarakat Indonesia. Adanya calo SIM di SATPAS Demak, menandakan bahwa masih dibutuhkannya sebuah perantara dalam sulitnya pengurusan SIM serta sebagai pembantu pemrosesan bagi mereka (masyarakat) yang tidak memiliki waktu luang yang lebih untuk mengurus SIM atau tidak menginginkan kekecewaan atas ketidaklulusan yang menyebabkan mereka bolak-balik ke Kantor pengurusan SIM. atas dasar itulah keeksisan para calo SIM masih terjaga.

Percaloan pada kepengurusan SIM membuat orang berfikir akan potensi momen tersebut untuk dijadikan sebagai ladang bisnis. Dapat dianalisis bahwa sesuai dengan hasil data yang tercatat, peneliti dapat menggambarkan latar belakang seseorang menjadi calo, sebagai berikut :

Tabel 1

Faktor adanya Calo SIM di SATPAS POLRES

Demak

\begin{tabular}{|l|l|l|l|l|l|l|}
\hline \multirow{2}{*}{ Faktor } & \multicolumn{7}{|c|}{ Informan } \\
\hline & I1 & I2 & I3 & I4 & I5 & I6 \\
\hline Orang dekat & $\checkmark$ & $\checkmark$ & & & $\checkmark$ & \\
\hline $\begin{array}{l}\text { Orang yang } \\
\text { dipercaya } \\
\text { mampu } \\
\text { menguruskan }\end{array}$ & & & & & & \\
\hline $\begin{array}{l}\text { Lemah } \\
\text { Financial }\end{array}$ & & & & & & \\
\hline
\end{tabular}

Dalam pembahasan di atas, dapat disimpulkan bahwa berbagai macam background yang disandang seorang calo. Ada yang berprofesi sebagai mantan sopir seorang KASATLANTAS POLRES Demak seperti ungkapan Pak Ngadimin dalam wawancara yang sudah kami dokumentasikan sebagai berikut:

"Pada saat itu (sekitar tahun 1977), saya menjadi sopir seorang Kepala SATLANTAS POLRES Demak. Beliau selalu meminta saya untuk mendampinginya sebagai sopir, karena memang kemampuan drive saya nyaman dan aman serta cocok untuk diajak ngobrol, sehingga beliau dapat dikatakan sebagai salah satu orang dekat, terkadang kalau saya ada acara dan tidak bisa mendampingi sebagai sopir, beliau menyesalkan hal itu, sampai pernah bilang kalau tidak kamu sopirnya, ya tidak berangkat, dan terpaksa saya harus mendahulukan urusan saya dengan beliau".

Sebagian ada yang berprofesi sebagai pedagang, seperti hasil wawancara dengan Pak Sarmadi dan Pak Agus.

Pak Sarmadi berkata bahwa:

"Ya, pas dagang wedang ronde, kadang saya dicurhati pembeli yang sekaligus orang yang ingin ngurus SIM. Dia mengeluh tidak berhasil 
tes komputer. Jadi, saya tawari. Bagaimana kalau saya yang tuntun?, begitu. Ya Alhamdulillah, bisa lulus dan dapet SIM. Ya hitung-hitung sebagai rizqi tambahan".

\section{Sedangkan Pak Agus mengatakan}

"Ya, sekarang ini, sejak saya jadi pensiunan Polisi, saya sibuk di warung dengan istri, kalau pas lagi sepi saya tinggal (warungnya), yang jaga istri sendirian. Saya jadi birojasa SIM, pas juga punya kenalan polisi. Ya bisa dibilang tambahan sehari-hari."

Sebagian lagi menjadi Anggota bagian dari birokrasi pemerintahan di tingkat desa, seperti Pak Mubin dan Pak Sarmadi yang sebagai anggota BPD Desa, yang mana sudah melek akan alur-alur kepengurusan surat-surat dan tentunya kepengurusan SIM. Hal tersebut sesuai dengan pernyataan mereka.

Pak Mubin menyatakan :

"Ya, selain jadi Guru Wiyata Bhakti, saya juga di BPD waktu itu. Kalau BPD 'kan kerjanya pas ada musyawarah dan seringnya pas malam dan kegiatannya juga jarang, jadi waktu luang saya di malam hari bisa terisi di BPD. Nah, ketika di situ, saya mengerti banyak mengenai alur-alur pengurusan surat-surat, mulai dari KTP, Akte Kelahiran, KK (Kartu Keluarga), STNK (Surat Tanda Nomor Kendaraan), juga SIM. Lama kelamaan, kadang ada orang Tanya mengenai SIM, cara buat dan ngurusnya bagaimana?, lalu saya arahkan. Dan diminta untuk menemani ke lokasi, ya Alhamdulillah yang niatnya saya nolong malah juga dikasih sedikit-sedikit, ya sepantasnya".

Tak jauh beda dengan Pak Mubin, Pak Sarmadi (42 tahun) menjadi salah satu orang yang dipercaya masyarakat untuk kepengurusan SIM.

"Waktu itu, saya menjadi salah satu anggota BPD. Ya begitulah. Yang namanya BPD harus tahu keluh kesah masyarakat. Saat itu sudah tahu menahu sedikit banyak mengenai prosedur mengurus seperti begitu. Ya kadang ada orang bertanya, Bagaimana cara ngurusnya ini-itu, Bagaimana cara ngurus SIM dan sebagainya. Ya terkadang disuruh menemani ke Kantor pembuatan SIM. Ya, pas selesai urusan, saya dikasih uang jasa menemani dan mengarahkan tadi."
Ada pula yang berlatar belakang sebagai pengajar. Seperti halnya Pak Mubin. Beliau mengatakan bahwa gaji sebagai pengajar belum cukup untuk memenuhi kebutuhan keluarga.

"Di MI, saya ngajar sebagai guru beberapa pelajaran. Ya kalau sebulan itu tidak cukup untuk memenuhi kebutuhan keluarga. Jadi, saya nyambi-nyambi seperti ini. Kadang juga ngurusin Akte dan KK juga."

Namun, berbeda dengan yang lainnya, Pak Zainal Abidin merupakan seorang pelatih sekolah sepak bola, yang mana memang tak ada sangkut pautnya dengan hal semacam ini. Seperti ungkapannya dalam wawancara.

"saya ngurus-ngurus seperti ini ya karena memang jalannya begitu. Saya juga tidak minta jadi birojasa seperti ini, pun saya juga tidak menolak akan hal ini. Ya saya jalani saja. Mungkin ini salah satu jalan saya dapat rizqi”.

Berdasarkan dengan pembahasan tersebut dapat disimpulkan bahwa yang melatarbelakangi seseorang menjadi calo adalah faktor ekonomi dan faktor orang dekat serta faktor trust terhadap seseorang (calo) yang mana hal-hal tersebut dibarengi dengan adanya pengetahuan atas kepengurusan SIM.

\section{Akad (Contract) yang terjalin}

Akad/perjanjian mengatur hubungan keterikatan antara para pihak mengenai hak dan kewajiban yang memuat tentang identitas pihak-pihak terkait, di satu pihak dapat bertindak atas nama hukum atas hal-hal yang berkaitan dengan akad/perjanjian dimaksud dan di lain pihak bila tidak dapat melaksanakan janjinya maka akan menerima sanksi hukum sesuai dengan materi akad perjanjian yang telah disepakati bersama. Kedua belah pihak masing-masing telah terikat dengan perjanjian dan kesepakatan bersama sehingga para pihak dapat bertindak atas nama hukum dan memiliki status yang mengikat dalam suatu perjanjian dan akan mendapat sanksi bila ternyata terjadi hal-hal di luar kemampuan atau adanya dugaan pelanggaran atas akad (Djohar Arifin, 2014).

Dari sudut pandang bahasa, aqad memiliki bentuk jama' dari 'uqûd. Dalam literatur Arab, sinonim aqad adalah rabth, syaddu, tautsiq, ihkam, quwwah, kumpulan dari dua hal, dan al 'ahdu. Mengikuti pengertian bahasa ini, aqad seolah 
memiliki dua sisi pengertian, yakni hissi (inderawi) dan ma'nawi (bathin). Pengertian indrawinya (hissi), adalah sebagaimana ikatan dua ujung tali. Adapun pengertian ma'nawi dimaknai sebagai ikatan bathin, kontrak sosial, sebagaimana layaknya pernikahan, jual beli, berserikat, dan sebagainya. Persamaan dari kedua sudut pandang ini, titik persamaan dari pengertian aqad adalah berkumpulnya dua benda atau dua hal yang berbeda menjadi satu (Muhammad Syamsuddin, 2017).

Secara istilah, menurut Ibnu Rajab dalam kitabnya Al-Qaidah li Ibn Rajab: 73 aqad dalam fiqih dimaknai sebagai (Muhammad Syamsuddin, 2017).

$$
\begin{aligned}
& \text { العقد معنيان عام وخاص فالمعنى العام يطلق على كل } \\
& \text { التزام تعهد به الإنسان على نفسه سواء كان يقابله التزام } \\
& \text { آخر أم لانية وسواء كان التزاماً دينياً كالنذر أو دنيوياً كالبيع } \\
& \text { ونحوه وأما المعنى الخاص فيطلق العقد على كل اتفاق تم } \\
& \text { بين إرادتين أو أكثر على إنشاء التزام أو نقلهنية فهو لا }
\end{aligned}
$$

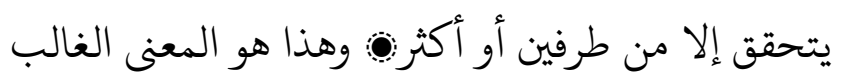

$$
\begin{aligned}
& \text { عند إطلاق الفقهاء للعقد فى الاصطلاح ح الفقهى }
\end{aligned}
$$

"Aqad ada dua makna, yaitu 'Am dan Khash. Makna 'Am aqad adalah sesuatu yang diucapkan karena adanya komitmen yang harus dipatuhi oleh diri dari seorang insan, baik ada hubungannya dengan orang lain atau tidak, termasuk urusan agama seperti nadzar, atau murni duniawi saja seperti jual beli dan sejenisnya. Adapun makna khas dari aqad adalah, suatu upaya menjalin kesepakatan yang sempurna (ittifaq tam) antara dua pihak yang memiliki kehendak atau lebih, agar tumbuh komitmen bersama atau bahan rujukan. Dengan demikian, maka berdasar pengertian khusus ini, aqad hanya terjadi bila ada dua pihak atau lebih yang saling berinteraksi. Pengertian terakhir inilah yang sering dipakai oleh para fuqaha' untuk memaknai aqad menurut istilah fiqihnya".

Pengertian di atas diringkas oleh Syekh Ibn Himam dalam kitabnya Faidlul Qadir 3/187, bahwasanya aqad diartikan sebagai (Muhammad Syamsuddin, 2017).

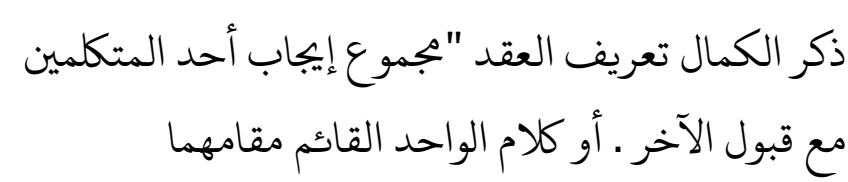

Syekh Al Kamal menyebut bahwa definisi aqad adalah "suatu kumpulan antara lafadh ijab dan qabul antara dua orang yang berbeda. Atau bisa juga diartikan sebagai: "Statemen pertama yang menjadi rule (aturan)."

Pendapat lain juga dijelaskan oleh Syekh Muhammad Qadary dalam kitabnya Mursyidul Hairaan, beliau menyatakan (Muhammad Syamsuddin, 2017).

$$
\text { بقبول الآخر على وجه مشروع يثبت "ارتباط الإيجاب الصادر من أحد المتعاقدين فى المعقود عليه }
$$

"Aqad ituu sesungguhnya merupakan rangkaian dari lafadh ijab dari salah satu dua pihak yang saling beraqad yang disertai dengan lafadh qabul pihak yang lain menurut cara-cara yang dibenarkan oleh syara' serta bersifat mengikat khususnya perihal yang diaqadkan (al-ma'qud 'alaih)."

Berdasarkan definisi ini, maka bisa ditarik adanya kesimpulan bahwa dalam aqad terdapat unsurunsur antara lain (1) shighat aqad yang terdiri atas lafadh ijab dan qabul, (2) dua pihak atau lebih yang beraqad, (3) dan perihal yang diaqadkan (al-ma'qûd 'alaihi). Setiap shighat (pernyataan) aqad memiliki keterikatan hubungan dengan niat. Seseorang ingin melakukan transaksi jual beli, maka keinginannya ini adalah hakikatnya niat. Sementara bentuk transaksinya antara ia dengan pembeli disebut sebagai shighat. Karena ada hubungan yang erat antara niat dan shighat, maka di sinilah titik berangkatnya aqad atau biasa disebut maqashid al 'aqdi (Muhammad Syamsuddin, 2017).

Tujuan akad harus jelas dan diakui syara'. Tujuan akad ini terkait erat dengan berbagai bentuk transaksi yang dilakukan. seperti dalam jual beli tujuannya adalah untuk memindahkan hak milik penjual kepada si pembeli dengan adanya imbalan. Demikian pula dalam akad ijarah atau sewa menyewa, dimana akad ini bertujuan untuk memiliki manfaat benda bagi orang yang menyewa dan pihak yang menyewakan mendapatkan imbalan (Sri Sudiarti, 2018).

Sebagaimana diketahui bahwa niat memegang peranan yang sangat penting dalam hukum fiqih. 


\section{Jurnal Ilmiah Ekonomi Islam, 7(01), 2021, 419}

Suatu kontrak/transaksi dihukumi sebagai benar atau tidak, sah atau tidak, adalah tergantung pada motivasi awalnya (niat). Jika suatu perbuatan dilakukan dengan niat yang tidak dibenarkan oleh Allah SWT, maka perbuatan itu dinilai tidak benar (bathil) di dalam kacamata fiqih/syariah, sehingga otomatis tidak mendapatkan pahala, bahkan dihitung sebagai kejahatan dan perbuatan dosa (Muhammad Syamsuddin, 2017).

Dalam aspek hukum, para ulama banyak sekali menitikberatkan pembahasan pada niat ini serta akibat-akibat yang mungkin ditimbulkannya. Para ulama juga telah meneliti banyak hal terkait dengan niat serta hubungannya dengan muamalah atau ibadah yang berhubungan dengan fiqih. Seperti dalam aqad transaksi bisnis, hukum keluarga, ibadah dan lain-lain. Mereka juga telah menentukan status dan posisi hukum suatu amal berdasarkan niat dan tujuannya. Sebagai contoh kaidah fiqih mereka yang terkenal (Muhammad Syamsuddin, 2017):

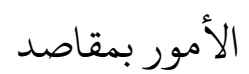

"Suatu perbuatan adalah tergatung pada maksudnya (niatnya)"

Suatu contoh, ada seseorang memberi hadiah kepada orang lain dengan niat menghindar dari hitungan nishab zakat. Maka, dalam hal ini, status hukum memberi hadiah tersebut, meski pada awalnya adalah boleh, menjadi tidak boleh (tidak sah) disebabkan karena adanya niat menghindari zakat. Sama halnya dengan niat seseorang yang niatnya adalah sebagai sarana menuju riba, maka jual beli semacam hukumnya adalah tidak sah disebabkan dilarangnya riba tersebut (Muhammad Syamsuddin, 2017).

Dalam kasus saddud dzari'ah, digambarkan ada seseorang memeras anggur dengan niatan untuk membuat cuka. Maka niat seperti ini menjadikan muamalah memeras anggur tersebut menjadi sah dan halal. Berbeda halnya dengan kasus, bilamana tujuan memeras anggur dimaksudkan untuk membuat khamr, maka hukum memerasnya dihukumi sebagai haram, disebabkan 'illah kerusakan dan keharaman khamr tersebut. Inilah contoh gambaran posisi niat terkait dengan aqad/transaksi kelak dipandang sah atau tidak. Kesimpulannya bahwa, suatu perbuatan dipandang sah, bilamana niatnya adalah benar dan tidak menimbulkan mudarat, kerusakan atau kemungkaran. Untuk selanjutnya, niat ini kemudian oleh para ulama digambarkan sebagai shighat (bunyi aqad), sementara dua orang yang melakukan transaksi disebut sebagai 'aqidain, dan barang yang diaqadkan dikenal sebagai al-ma'qud, kemudian tujuan akhir dari aqad kemudian dikenal sebagai al-ma'qud 'alaih (Muhammad Syamsuddin, 2017).

Jika diuraikan lebih lanjut, dalam kasus anggur di atas, shighat aqad adalah jalinan antara pengusaha dan petani anggur. Pengusaha menyuruh petani untuk menanam anggur mau digunakan sebagai apa. Jika pengusaha memberi tahu petani bahwa anggurnya kelak akan dipakai untuk memproduksi minuman keras, misalnya, maka menjualnya petani untuk hasil panen anggurnya kepada pengusaha, hukumnya menjadi tidak boleh. Pemberitahuan pengusaha kepada petani terkait kegunaan anggurnya kelak diibaratkan sebagai sebab aqad yang memperantarai terbentuknya shighat. Pengusaha dan petani anggur disebut 'aqidain. Anggur hasil panenan disebut al ma'qud. Dan tujuan transaksi untuk membuat minuman keras disebut al-ma'qud 'alaih (Muhammad Syamsuddin, 2017).

Dalam praktek yang dilakukan oleh Calo SIM di SATPAS POLRES Demak dengan Pengguna jasanya adalah orang yang memberikan jasa dengan orang membutuhkan jasa (bantuan). Hal ini termasuk dalam akad Ijarah.

Hal ini sesuai dengan beberapa pernyataan Calo saat wawancara. Pak Mubin mengutarakan bahwa uang upah yang diberikan pengguna jasanya adalah uang upah atas arahan dan pendampingan ke lokasi.

"Kadang ada orang sekitar sini, meminta tolong kepada saya untuk menuntun dan mengarahkan pengurusan SIM. Ya saya hanya mengarahkan tahapan-tahapan yang harus dilalui dan mengantarnya ke lokasi. Seusai proses itu saya dan orang itu pulang dan saya diberi uang, mungkin dia sadar diri karena ada waktu dan tenaga saya yang tergunakan karena kepentingan dia mengurus SIMnya itu".

Sama dengan Pak Mubin, akad yang dibangun oleh Pak Sarmadi merupakan akad ijarah dengan maksud diberikan upah sepantasnya.

"Ya kalo saya biasanya, orangnya saya antar ke lokasi, terus saya jelaskan tahapannya dan kemudian dia menjalani tahapan. Kalau lulus ya Alhamdulillah, saya dapat uang dari orangnya itu sepantasnya. Tapi Kalau tidak lulus, Ya saya kadang mendapat uang ganti bensin saja kadang 
juga tidak, karena memang belum dapet hasil (berupa) SIM itu".

Ada perbedaan pada transaksi dengan Calo yang disebutkan diatas, bahwasanya Pak Agus dan Pak Ngadimin langsung mematok harga untuk pengurusan SIM, dan memastikan bahwa akan lulus.

Pak Agus mengatakan

"Kalau buat baru SIM C itu, di saya cuma Rp. 420.000, kalau perpanjang ya Rp. 120.000. Di sini harga rata segitu, kalau diluar kota (Luar Demak) malah mungkin lebih mahal"

Sedangkan Pak Ngadimin juga mengatakan hal yang sama

"SIM C di Demak Rp. 420.000, Kalau perpanjangan itu Rp.120.000. Ya umum lah segitu kalau dengan birojasa disini”

Sama halnya dengan pernyataan para calo, pengguna jasa calo pun menyatakan bahwa hal ini termasuk dalam akad ijarah, yang mana besaran upah dari seorang calo tidak diutarakan secara jelas nominalnya.

Hal tersebut sesuai dengan pernyataan Ainun,

"Nggak ada perjanjian khusus, cuma disuruh bayar aja kalau SIM sudah jadi”

Sedangkan, Saidatun Nisa' menyatakan,

"pembayaran SIM di awal, habis itu SIM diberikan 15 menitan setelah bayar tadi"

Tak jauh beda dengan Nisa', Dian Putri mengatakan hal demikian,

"ditawari jadi cepat tanpa ribet, terus bayar, terus nunggu jadi. udah"

Senada dengan penyataan Nisa' dan Dian, Fakhrul Huda pun memnayatak seperti ini

"dia menghampiri saya, langsung dianya ngomong ke saya, mau perpanjang atau buat baru, saya bilang 'baru', kata dia 420 jadi, gampang".

Pernyataan para pengguna jasa dapat dianalisis bahwa akad yang terjalin adalah akad Ijarah. Yang mana para calo mengatur besaran upahnya sendiri untuk dijadikan sebagai imbal atas menjual jasanya.

Akad ijarah dilegalkan di dalam syariat berdasarkan nash Al-Qur'an, Hadits dan Ijma' sebagaimana yang disampaikan oleh Syekh Zakariya al-Anshari. Allah subhanahu wata'ala berfirman:

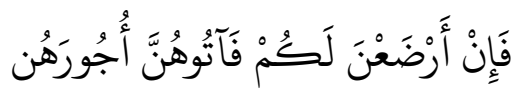

"Kemudian jika mereka menyusukan (anakanak)mu untukmu maka berikanlah kepada mereka upahnya." (QS Ath-Thalaaq: 6)

Ayat ini menunjukan tentang akad ijarah sebab bentuk kalimat فَاتَوهُنَّ أُجُورَهُنَ adalah bentuk kalimat perintah dan perintah di dalam ushul fiqh menunjukkan wajib. Upah hanya bisa diwajibkan/ditetapkan oleh akad (transaksi). Sehingga ayat ini secara pasti diarahkan pada menyusui yang disertai dengan akad (ijarah).

Di dalam sebuah hadits disampaikan:

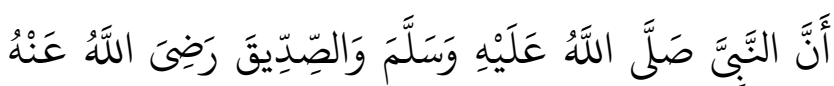

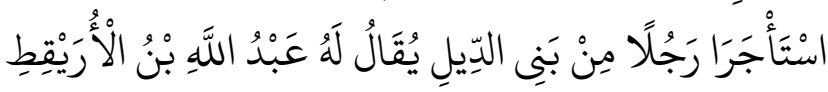

"Sesungguhnya baginda Nabi shallallahu 'alaihi wasallam melarang muzara'ah dan memerintahkan muajjarah (akad sewa). Beliau bersabda, 'Tidak apa-apa melakukan muajjarah." (HR Muslim)

Makna Ijarah Secara bahasa ijarah memiliki arti nama untuk sebuah upah. Sedangkan secara istilah syariat adalah

$$
\text { عقد على منفعة مقصودة معلومة قابلة للبذل }
$$

“Akad (transaksi) terhadap kemanfaatan yang maqshudah, maklum, bisa untuk diserahkan dan mubah dengan 'iwadl (upah) yang maklum"

Maksud 'manfaat maqshudah' adalah manfaat menurut pandangan syariat maka tidak boleh menyewa uang untuk hiasan. Maksud 'manfaat yang maklum' adalah manfaat yang jelas dan dibatasi seperti menyewa orang untuk menjahit baju dengan ukuran dan model tertentu. Maksud 'bisa untuk diserahkan' adalah mungkin untuk diserahkan, maka tidak boleh menyewakan Al-Qur'an kepada orang kafir, sebab Al-Qur'an tidak bisa diserahkan kepada orang kafir. Maksud 'manfaat yang mubah' adalah manfaat yang tidak haram, maka tidak boleh menyewa alat-alat musik yang diharamkan (Muhammad Syamsuddin, 2017).

Transaksi ijarah hukumnya sah jika memenuhi rukun-rukun yang ada di dalamnya. Adapun rukun ijarah yaitu; Pertama, shigat (kalimat yang digunakan transaksi) seperti perkataan pihak yang menyewakan "Saya menyewakan mobil ini padamu selama sebulan 


\section{Jurnal Ilmiah Ekonomi Islam, 7(01), 2021, 421}

dengan biaya/upah satu juta rupiah." Dan pihak penyewa menjawab "Saya terima." Kedua, ujrah (upah/ongkos/biaya). Ketiga, manfa' at (Kemanfaatan barang atau orang yang disewa). Keempat, mukri/mu'jir (pihak yang menyewakan). Kelima, muktari/musta'jir (pihak yang menyewa) (Muhammad Syamsuddin, 2017).

Masing-masing dari kelima rukun memiliki syarat-syarat tertentu yang harus terpenuhi agar transaksi ijarah yang dilakukan bisa sah dan legal menurut syariat. Shighat: Sebagaimana transaksitransaksi yang lain, di dalam ijarah juga disyaratkan shigat dari pihak penyewa dan pihak yang menyewakan dengan bentuk kata-kata yang menunjukan terhadap transaksi ijarah yang dilakukan sebagaimana contoh di atas. Ujrah/upah/ongkos: Ujrah di dalam akad ijarah harus diketahui, baik dengan langsung dilihat ataupun disebutkan kriterianya secara lengkap semisal 'seratus ribu rupiah.' Manfaat: harus mutaqawwamah (bernilai secara syariat), maklum, mampu diserahkan, manfaat dirasakan oleh pihak penyewa, manfaat yang diperoleh pihak penyewa bukan berupa barang. Penyewa dan pihak yang menyewakan: Baligh, berakal, tidak terpaksa (M. Sibromulisi, 2017).

Dilihat dari objeknya, ijarah dapat dibagi menjadi dua macam, yaitu ijarah yang bersifat manfaat dan ijarah yang bersifat pekerjaan. Ijarah yang bersifat manfaat. Akad sewa menyewa dibolehkan atas manfaat yang mubah, diumpamakan sewa-menyewa rumah, toko, kendaraan, dan pakaian untuk dipakai (pengantin). Adapun manfaat yang diharamkan maka tidak boleh disewakan, karena barangnya diharamkan, seperti bangkai dan darah. Selanjutnya yakni Ijarah atas pekerjaan atau upah-mengupah adalah suatu akad ijarah dengan cara mempekerjakan seseorang untuk melakukan suatu pekerjaan. Ijarah semacam ini dibolehkan seperti buruh bangunan, tukang pijat, tukang jahit, dan lain-lain (Ali Hasan,2003).

Orang yang melakukan pekerjaan disebut ajir atau tenaga kerja. Ajir atau tenaga kerja ada dua macam, yakni Pertama, Ajir Khusus, yaitu orang yang bekerja pada satu orang untuk masa tertentu. Kedua, Ajir Musytarak, yaitu orang yang bekerja untuk lebih dari satu orang, sehingga mereka bersekutu di dalam memanfaatkan tenaganya (Ahmad Wardi Muslich, 2010).

Dengan demikian, sesuai dengan praktik di lapangan bahwa calo SIM tergolong dalam Ijarah yang bersifat pekerjaan bukan bersifat manfaat suatu benda yang dipersewakan. Karena yang dihasilkan adalah jasa kerja calo SIM. Dan mereka ada yang menjalani aktifitas percaloan mencakup semua jenis ajir atau tenaga kerja calo, baik itu ajir khusus ataupun Musytarak.

Adapun Ajir Khusus dapat ditemui langsung di lokasi. Sedangkan Ajir Musytarak, biasanya orang yang sebagai lantaran mempertemukan atau menunjukkan ke Ajir Khusus, bahwa ada orang yang ingin menguruskan SIMnya lewat calo. Jadi, fee seorang ajir musytarak bisa dari pengguna jasa atau pun dari ajir Khusus yang menguruskan SIMnya tadi.

Berdasarkan pembahasan tersebut, dapat disimpulkan bahwa transaksi akad ijarah yang dilakukan oleh Calo dan pengguna jasa calo adalah sah. Karena semua rukun telah tercapai baik dari kedua belah pihak, sighat, dan manfaat yang didapat.

\section{Islamic Framing terhadap Kepengurusan SIM oleh Calo (Broker)}

Menurut keyakinan umat Islam, bahwa Islam merupakan agama yangsempurna. Kesempurnaannya karena merupakan agama yang universal, tidak hanya mengatur hubungan manusia dengan Tuhannya akan tetapi membicarakan pula perihal bagaimana hubungan manusia dengan sesamanya yang dikenal dengan istilah mu'amalah (Darmawati, 2018).

Manusia sebagai mahluk sosial zoon political (C.S.T. Kansil, 1983). Maka dapat dipahami bahwa manusia dalam menjalankan aktivitasnya dalam kehidupan di dunia ini mendorong untuk saling berhubungan antara satu dengan lainnya, agar dapat memenuhi kebutuhannya.

Dengan adanya hubungan satu sama lain, maka dibutuhkan satu hukum yang dapat mengatur hubungan tersebut, sebab jika tidak ada hukum yang mengaturnya, maka kehidupan manusia dalam hal berhubungan antara satu dengan yang lainnya, akan terjadi kekacauan dan ketidakstabilan dalam kehidupan manusia. Salah satu bentuk aturan hukum yang sangat dibutuhkan dalam masyarakatadalah aturan hukum mengenai akad dalam transaksi ekonomi syari'ah. Aturan ini berfungsi untuk tetap menjaga stabilitas dalam kehidupan masyarakat, sehingga masyarakat dalam melakukan transaksi tetap dalam hal-hal yang sesuai dengan syariat (Darmawati, 2018).

Wajar sebagai umat Islam, dalam melakukan aktivitas-aktivitas ekonomi sesuai dengan aturan dan kaidah Islam.Islam sebagai satu agama, harus disadari tidak selalu mengurusi masalah ukhrawi saja, tetapi 


\section{Jurnal Ilmiah Ekonomi Islam, 7(01), 2021, 422}

Islam juga mengatur dan mengurusi masalah kehidupan duniawi.Karena itu satu sitem ekonomi yang didasrkan pada konsep Islam, adalah sebuah sistem ekonomi yang siap mengantarkan umatnya kepada kesejahteraan sebenarnya. Yaitu satu kesejahteraan yang tidak hanya terpenuhi kebutuhan jasmani manusia, melainkan juga kebutuhan rohani, mengingat esensi manusiajustru terletak pada rohaninya (Darmawati, 2018).

Aktivitas-aktivitas ekonomi itu merupakan aktivitas mu'amalah, maka dalam sektor ekonomi, misalnya yang merupakan prinsip adalah larangan riba, sistem bagi hasil, pengambilan keuntungan, pengenalan zakat, dan lain-lain. Oleh karena itu tugas bagi para cendikiawan muslim sepanjang zaman dalam mengembangkan teknik penerapan prinsipprinsip ekonomi tersebut yang sesuai dengan situasi dan kondisi pada setiap masa (Darmawati, 2018).

Praktek makelar boleh hukmunya, sebab kegiatan makelar merupakan salah satu bentuk penunjuk dan perantara. Ia sering mempermudah kedua belah pihak atau salah satunya untuk mendapatkan kemanfaatan. Prantara (makelar, atau dalam istilah bisnis modern dinamakan broker ) dalam transaksi bisinis di masa sekarang lebih terasa dibutuhkan disbanding pada masa-masa sebelumnya. Hal itu disebabkan oleh rumitnya transaksi bisnis saat ini, hal itu yang menjadikan peran broker sangat penting. Tidak ada salahnya seorang makelar mengambil upah yan tertentu bilangannya, atau hasil peersentase dari keuntungan, atau dibuat kesepakatan antar mereka (Yusuf Qardhawi, 2003).

Sebagaimana hasil penelitian yang dipaparkan penulis diatas, bahwa kepengurusan SIM oleh Broker dengan pengguna jasa termasuk dalam akad ijarah dan merupakan hal yang sah. Berdasarkan hasil analisis diatas profesi Calo SIM menggunakan sistem akad yang sama dengan akad Ijarah dalam pelaksanaan transaksinya. Yaitu adanya kedua belah pihak yang saling bertransaksi yang menyebabkan perpindahan sebuah manfaat dari jasa khususnya kepengurusan SIM, yang kemudian apabila manfaat tersebut sudah berpindah maka salah satu pihak akan memberikan ujrah berupa uang sebagai alat tukar dari manfaat yang sudah diterimannya (Muhammad Fatah Ilhamy dan A'rasy Fahrullah, 2019).

Dalam pandangan hukum Islam sendiri transaksi makelar dibolehkan dan sudah terdapat dalam dasar hukum nya yaitu Al qur'an surah Al- Maidah : 2 menjelaskan bahwasan nya pelaksanaan transaksi muamalah yang menggunakan makelar sudah disyariatkan oleh hukum Islam untuk dilaksanakan namun dalam pelaksanaannya haruslah memperhatikan beberapa aturan yang ada di dalamnya.

Dalam analisis peneliti bahwasannya secara keseluruhan dari mulai pengguna jasa, broker dan pemroses penerbitan SIM (SATPAS POLRES Demak) terdapat beberapa hal yang menjadikan pelaksanaan percaloan ini menjadi bertentangan dengan hukum Islam yakni objek percaloan SIM.

Hal tersebut yakni melanggar kepatuhan terhdap aturan pemerintah yang mana telah dijelaskan dala UU Nomor 11 tahun 1980 yang mana isinya larangan memberikan suap kepada calo. Dengan aturan tersebut,sudah sangat jelas bahwa obyek percaloan SIM itu dilarang. Hal ini didasari dengan perintah mentaati pemerintah atau Ulil amri pada Q.S An-Nisa' ayat 59 yang berbunyi:

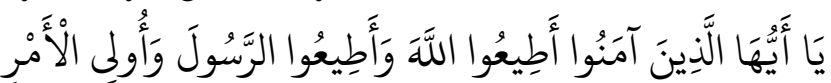

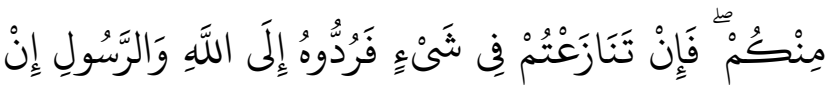

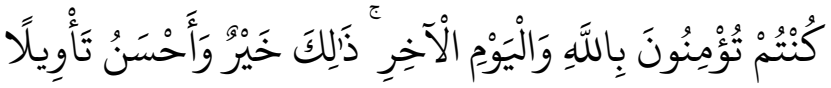

"Hai orang-orang yang beriman, taatilah Allah dan taatilah Rasul (Nya), dan ulil amri di antara kamu. Kemudian jika kamu berlainan pendapat tentang sesuatu, maka kembalikanlah ia kepada Allah (Al Quran) dan Rasul (sunnahnya), jika kamu benar-benar beriman kepada Allah dan hari kemudian. Yang demikian itu lebih utama (bagimu) dan lebih baik akibatnya."

Di dalam ayat tersebut di atas terdapat kata ulil amri yang berarti orang-orang ahli agama (ulama) dan dapat pula berarti umara yang berarti penguasa di bidang kepemerintahan (pimpinan formal) (Syarif Zubaidah, 2002).

Dalam Islamic Framing, yang menjadikan kepengurusan SIM oleh calo bersifat haram adalah karena ada unsur rishwah yang ada di dalamnya. Yakni tindakan ini tidaklah dilakukan pengguna jasa dan tidak diperlihatkan oleh calo kepada pengguna jasa, namun tindakan yang dilakukan oleh calo kepada pihak SATPAS menjadikan profesi calo yang mekanismenya seperti ini adalah haram. Sehingga memang dalam akad kepengurusan SIM yang dijalin oleh Calo dan pengguna jasa adalah sah. Dan pengguna jasa tidak dihukumi larangan atau melakukan tindakan yang haram. 
Hal ini sesuai apa yang diutarakan oleh para calo, yang mana harus membayar lebih ke bagian petugas agar hal tersebut dapat dipercepat hal ini sebagaimana yang disampaikan oleh responden kami Pak Zainal Abidin mengatakan,"ya, ditulis kode di form, nanti bisa". Sedangkan, responden kami Pak Nurdin berkata, "Ya, bayar ke dalam mas, kan kita juga ga tega ambil untung segede itu.", Sama halnya dengan Pak Zainal, Pak Mubin pun berkata demikian,"Ya, kalau disitu itu ngasih 250, nanti ditulis kode, tanda orang birojasa, gitu". Mirip dengan pernyataan Pak Nurdin, hal sama dikatakan oleh Pak Agus, "Ya, kita ngasih ke sana (ke biar dicepetin", Tak jauh beda, Pak Ngadimin juga berkata demikian "Ya, di sini masih 250 sih, ngasihnya".

bnu Hajar al Asqalani di dalam kitabnya Fath al Baari telah menukil perkataan Ibnu al Arabi ketika menjelaskan tentang makna risywah sebagai berikut :

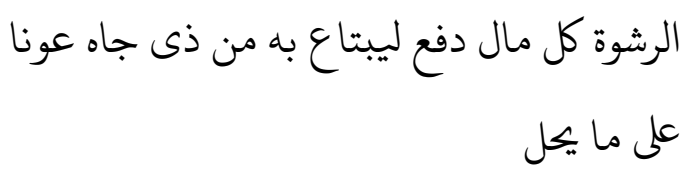

"Risywah atau suap-menyuap yaitu suatu harta yang diberikan untuk membeli kehormatan/ kekuasaan bagi yang memilikinya guna menolong/melegalkan sesuatu yang sebenarnya tidak halal."

Adapun menurut MUI suap (risywah) adalah pemberian yang diberikan oleh seorang kepada orang lain (pejabat) dengan maksud meluluskan suatu perbuatan yang batil (tidak benar menurut syariah) atau membatilkan perbuatan yang hak (Haryono, 2017).

Alqur'an menerangkan bahwa Risywah merupakan kejahatan yang dilarang dalam Islam begitu juga tindakan tercela dalam kehidupan manusia. Dikatakan kejahatan karena memang di dalam prakteknya sarat dengan manipulasi dan kezhaliman terhadap sesama (Haryono, 2017).

Dari paparan diatas, dapat disimpulkan bahwa secara keseluruhan profesi calo kepengurusan SIM tidak diperbolehkan karena beberapa sebab diantaranya melanggar aturan hukum negara yang dapat merusak tatanan hukum dan mengacaukan sistem administrasi yang semula berjalan sesuai dengan SOP; hal lain yakni mengandung unsur risywah yang dilarang oleh Islam yang dapat mengakibatkan kerusakan kehidupan sosial yang tak harmonis, menghalangi dana orang sholih kepada yang berhak, dan dalam hal lain menimbulkan orang yang tidak berkompeten dan bukan ahlinya bisa menduduki jabatan teratas sehingga etos kerja dan kualitas tidak sesuai dengan yang diharapkan.

\section{KESIMPULAN DAN SARAN \\ a. Kesimpulan}

Berdasarkan analisis dan pembahasan dari data Broker Kepengurusan SIM dalam Islamic Framing, maka dapat ditarik kesimpulan sebagai berikut:

1) Faktor yang melatarbelakangi seseorang menjadi calo SIM yakni karena lemahnya financial, sebagai orang dalam, sebagai orang yang diberi kepercayaan masyarakat mampu mengurusnya.

2) Akad yang terjalin antara calo SIM dan pengguna jasa dalam kepengurusan SIM adalah Akad Ijarah. Dan transaksi akad ini merupakan hal yang sah.

Secara menyuluruh, proses mekanisme kepengurusan SIM oleh Calo adalah haram. Karena ada unsur risywah atau suap-menyuap pada mekanismenya tersebut. Hal ini dapat mengakibatkan kerusakan kehidupan sosial yang tak harmonis, menghalangi dana orang sholih kepada yang berhak, dan dalam hal lain menimbulkan orang yang tidak berkompeten dan bukan ahlinya meraih apa yang diinginkan dengan jalur khusus yang tidak sesuai.

\section{b. Saran}

Berdasarkan hasil penelitian di atas, adapun saran yang diberikan untuk penelitian selanjutnya meliputi:

1) Pada penelitian ini penulis menggunakan 6 informan, disarankan bagi peneliti selanjutnya, untuk menambah jumlah informan agar mendapatkan analisa yang lebih luas.

2) Pemerintah diharapkan dapat mengembangkan strategi yang baik untuk menindaklanjuti keeksistensian calo SIM dan sistem daripada SATPAS Demak sendiri, agar menjadi lebih baik diberbagai pihak, baik dari pihak seseorang yang menjadi calo, pengguna jasa, dan juga pelayanan SATPAS Demak.

\section{UCAPAN TERIMA KASIH}

Peneliti mengucapkan banyak terimaksih kepada Allah SWT yang memberikan hidayahnya sehingga tulisan ini bisa selesai. Tidak lupa kami ucapkan terimakasih juga kepada seluruh pihak yang telah membantu selesainya penelitian ini, kemudian kepada pengelola jurnal ilmiah Ekonomi Islam STIE AAS Surakarta yang telah berkenan menerbitkan artikel ini kami ucapkan terimakasih yang sebesar-besarnya.. 


\section{REFERENSI}

Al Asqolani, I. H., (1994) Fathul Bari (Tahqiq Ibnu Baz dan Muhibbudin al Khotib). Dar al Fikr Beirut.

An-Najah, A. Z. (2019) "Hukum Calo Dalam Islam." 25 Juli. http://www.ahmadzain.com/read/karyatulis/413/hukum-calo-dalam-islam/

Antonio, M. S., (2001) Bank Syari'ah Teori Ke Praktek.Cetakan 1. Jakarta: Gema insani, 2001.

Berthania, R., (2017) "Kedudukan Makelar dalam Transaksi Jual Beli Kendaraan Bermotor ditinjau dari Hukum Islam.” Skripsi, Universitas Lampung. : $1-84$

Darmawati, H,. (2018) "Akad dalam Transaksi Ekonomi Syariah.” Jurnal Sulesana, Vol. 12 No. 2, (2018) : 143-144.

Daymon, C and Holloway, I. (2002) "Qualitative Research Methods in Public Relations and Marketing Communications". New York: Routledge, 2002.

Haryono. (2017). "Risywah dan Perbedaannya dengan Hadiah dalam Padangan Hukum Islam.” Jurnal Al Maslahah (Jurnal Hukum dan ranata Islam), 432-433.

Hasan, A. (2003) Berbagai Macam Transaksi Dalam Islam (Fiqh Muamalah). Jakarta: PT Raja Grafindo Persada, 2003.

Ilhamy, M. F. dan Fahrullah, A. "Tinjauan Hukum Islam Terhadap Akad Ijarah Dalam Kepengurusan SIM Melalui Jasa Makelar." Jurnal Ekonomi Islam, Volume 2, No. 1. (2019): $34-48$

KBBI Daring. 31 Januari, 2019. https://kbbi.kemdikbud.go.id/.

KBBI ONLINE. 25 Juli, 2019. https://kbbi.kemdikbud.go.id/entri/CALO.

Laksmita, A. H. M dan Wahyudi, A. (2017), "Rasionalitas Pengguna Jasa Calo dalam Pengurusan SIM Baru di Polres Sidoarjo." Jurnal Paradigma 05 No. 01: 1-7.

Mahalli, A. M. (2004) Hadits-hadits Muttafaq 'alaih Bagian Munakahat dan Mu'amalat. Jakarta: Prenada Media.

Nindito, S. (2005) "Fenomenologi Alfred Schutz: Studiteentang Konstruksi Makna dan Realitas dalam Ilmu Sosial." Jurnal ILMU KOMUNIKASI, Volume 2, No. 1. : 79 - 94

Noor, J. , (2012). "Metodologi Penelitian". Jakarta: Prenada Media Group.

Pass, C., Lowes, B. dan Davies, L. (2019) Kamus Lengkap Ekonomi. Jakarta: Erlangga.
POLRI, (2012) Peraturan Kepala Keoplisian Negara Republik Indonesia Nomor 9 Tahun 2012 Tentang Surat Izin Mengemudi. Jakarta.

POLRI. (2019)“Surat Izin Mengemudi.” 29 Juli. https://polri.go.id/layanan-sim.php.

Qardhawi, Y. (2003). Al-Halal wal Haram fil Islam. Solo : Era Intermedia, 2003.

Raco, J.R. (2010). Metode Penelitian Kualitatif : Jenis, Karakteristik, dan Keunggulannya". Jakarta: PT. Grasindo, 2010.

Saldana, J. (2011) "Ethnotheatre: Research from page to stage" New York: Left Coast Press, 2011.

Sibromulisi, M. (2019) "Definisi dan Rukun Ijarah, Sewa-Menyewa dalam Islam", $N U$ Online, 30 Oktober 2019. https://islam.nu.or.id/post/read/84810/definisidan-rukun-ijarah-sewa-menyewa-dalam-islam

Sudiarti, S. (2018) Fiqh Muamalah Kontemporer. Cet. I. Medan: FEBI UIN-SU Press, 2018.

Syamsuddin, M., (2019) "Kajian Fiqih Muamalah Terapan: Akad", NU Online, 30 Oktober 2019. https://islam.nu.or.id/post/read/83180/kajianfiqih-muamalah-terapan-akad

Yusuf, M. (2007). "Metode Penelitian: Kuantitatif, Kualitatif, dan Penelitian Gabungan”. Jakarta: Prenadamedia Group, 2017.

Zubaidah, S. (2002) "Kepemimpinan Dalam Perspektif Politik Umat Islam". Jurnal Al Mawarid Vol $8: 3$.

"Bangsa Indonesia Bermental Calo: Sebuah Gejala Bahasa". Kompasiana, 29 Januari, 2014.

"Pengertian Calo." Sudut Hukum. 8 Juli, 2017, https://www.suduthukum.com/2017/07/ pengertian-calo.html.

Agus, wawancara oleh penulis, 25 Oktober, 2019, pukul 13.58 WIB, di Mushola SATPAS POLRES Demak,

Ainun, wawancara oleh penulis, 31Oktober, 2019, pukul 12.22 WIB, wawancara pengguna jasa

Putri, D., wawancara oleh penulis, 31Oktober, 2019, pukul 14.11 WIB, wawancara pengguna jasa

Huda, F., wawancara oleh penulis, 31Oktober, 2019, pukul 13.20 WIB, wawancara pengguna jasa

Mubin, wawancara oleh penulis, 15 Oktober, 2019, pukul 20.02 WIB, di Kediaman

Ngadimin, wawancara oleh penulis, 16 Oktober, 2019, pukul 20.36 WIB, di Kediaman,

Nisa', S., wawancara oleh penulis, 31Oktober, 2019, pukul 13.50 WIB, wawancara pengguna jasa

Sarmadi, wawancara oleh penulis, 18 Oktober, 2019, pukul 20.50 WIB, di Kediaman,

Abidin, Z., wawancara oleh penulis, 18 Oktober, 2019, pukul 21.11 WIB, di Kediaman 